\title{
A broadly narrow map of intellectual traditions
}

\section{[ B O O K R E VIE W ]}

Vale, Peter, Hamilton, Lawrence \& Prinsloo, Estelle H (eds) (2014) Intellectual traditions in South Africa: Ideas, individuals and institutions. Pietermaritzburg: University of KwaZulu-Natal Press. ISBN 978-1-86914-258-2 pbk. Pages xii + 364.

\section{Hugo Canham}

Department of Psychology, University of the Witwatersrand, Johannesburg hugo.canham@wits.ac.za

While reading this book, an article that I had written was being reviewed by a North American based journal. When I did get feedback, the greatest criticism was that I had centred American scholarship to explain South African phenomena. A reviewer strongly argued that South Africa had a long and deep tradition of scholarly reflection on the subject I had written about. As I mulled over this feedback, I began reading Part Two of Intellectual traditions in South Africa. What the reviewer of my article had pointed me to was neatly packaged in this section of the book. Mcebisi Ndletyana, Mabogo P More and Raymond Suttner were my guides in refining my literature so as to enable me to foreground local and Africanist scholarship. Here was a map on African Nationalism, Pan Africanism in South Africa, and the intellectual foundations of the Black Consciousness Movement (BCM). The value of the book lies in this small example. The book is a go to guide for our very own intellectual traditions. The subject makes this a foundational text for those wanting to think deeply about South Africa and its place in the world of ideas.

Like any text that strives to be a map of the lie of the land, the book has strengths and shortfalls. I start by reflecting on some of its limitations before engaging with its strengths. Given what Anthony Egan calls its "broadly narrow" scope, 
points of emphasis were always going to be a challenge of this text. For instance, while understandable, why do some subjects command more focus than others? Helen Moffett's essay titled, Feminism and the South African polity: A failed marriage, is a sharp and incisive reflection on the local feminist movement but there is much more that could be said about feminism in South Africa. This is not a criticism of a fine essay but a suggestion that the editors could have given feminism greater space in this text.

Since the text is also about individuals that shaped South African thought and no female figure receives meaningful attention, more effort should be expended to integrate women's movements into the scholarly history of this country. Phyllis Ntantala, Ellen Kuzwayo and others made seminal contributions to our intellectual traditions. If the inherent sexism in our scholarship has treated these women as marginal figures, texts like this provide an opportunity to rewrite them into the centre of our thinking. The historic women's movement in the Free State and march on the Union Buildings must surely have influenced BCM thinkers and other resistance movements in the region. We need to see an intellectual interrogation of these links.

Figures like Gandhi as profiled in the essay by Uma Dhupelia-Mesthrie productively illustrate the movement of thought between South Africa and India. However, while Dhupelia-Mesthrie's essay does a great job of giving life to Gandhi during his time in South Africa, we read little about a part of him that has emerged as having been prejudiced in his thinking about his African countrymen. This was a moment to reflect on the limits of activism during a time when the world was overcome by colonial ethnic chauvinism. This has lessons for the contemporary moment when we think about South African Indian - African relations and the historic antecedents. To see the contradictions of Gandhi, a comparison of the Dhupelia-Mesthrie essay and that of Steven Friedman is insightful. In his essay, The ambiguous legacy of Liberalism: Less a theory of society, more a state of mind, Friedman navigates the tightrope between highlighting the positive contributions of South African liberalism and its shortfalls and how these continue to influence South African thought. This comparison is to illustrate the point that it is both possible and desirable to tell a nuanced history.

Another criticism of the book is that it does not overtly interrogate the role of whiteness in the South African intellectual tradition. The place to do this would have been in an essay to accompany that of Friedman. Peter Duvenage's contribution titled, Afrikaner intellectual history: An interpretation, is not an analysis of whiteness. The essay on the Genealogy of South African positivism by Christopher John Allosobrook gestures towards the formation and operation of white unity, but this too is not an overt exposition of whiteness as an intellectual tradition. Whiteness as Melissa Steyn (2001) has shown elsewhere is insidious and does not announce its presence and operation. It was

PINS [Psychology in Society] 48 • $2015 \mid 98$ 
primarily through the liberal tradition that whiteness operated. Its low level operation allowed it to hide behind the bogeyman of Afrikanerdom. I suspect that it was more organised and conscious as an intellectual tradition than we give it credit for.

If one is interested in a crash course on Marxism in South Africa, Andrew Nash's essay on The double lives of South African Marxism is a concise and thought provoking contribution. The peculiar circumstance of South Africa and Marxism is that colonialism, apartheid and the relatively high number of white people in an African country, made race contextually very important. While the logic of a class centred reading in Europe and other international locals made sense there, an analysis that evacuated race in South Africa was complicit in maintaining race-based inequality. The intellectual debate would of course have had to reflect on the race - class dualism. Nash accomplishes this handsomely. He shows that a hegemonic imposition of a grand theory on a context founded on race-based dispossession was always going to be fraught. Here the figure of Moses Kotane is analysed to illustrate the race-class contradiction. Kotane's appearance in the text is timely as I was beginning to bemoan the absence of black figures in Part One of the book. While I do not think that this was the intention of the editors, partitioning Part One as the white intellectual tradition and Part Two as the black tradition gives the mistaken impression that these histories unfolded in isolation. The section headings are however instructive as they organise the book in three parts: Inherited Ideas, Transplanted Institutions and Local Critiques; Resistance to Domination, African and Asian Alternatives; Religious Dogma and Emancipatory Potential. These sections are a useful organisation of ideas but the reader should not lose sight of the fact that history unfolds in a messy and more unordered manner.

However, from latter parts of the text, there is an overpowering sense that the local communities were being acted upon with little agency to act on the incoming Jewish or Indian communities. This is symptomatic of the grand colonial trope which would have it that African communities were passive recipients of intellectual traditions without reciprocal influences. There is a lack of bi-directional influence particularly in the part of the book that addresses religious dogma. The essay on Hinduism by Vashna Jagarnath is less guilty of this when compared to Jewish responses by Sally Gross. The latter begins by acknowledging that specific Jewish strands of philosophical influences have been narrowly intra-communal. She however goes onto show that Judaism through Christianity was a crucial influence in Nongqawuse's prophesy which led the Xhosa people to destroy their crops and cattle. While this may well be true, the book does not offer a counter narrative which illustrates how an African or "indigenous" intellectual tradition might have informed the same incident. For this counter narrative, we have to read Part Two of the text but also look beyond this book. Xolela Mangcu's Biko: A biography (2012) traces lineages of African thought in the Eastern Cape and 
Hlonipha Mokoena's Magema Fuze: The making of a Kholwa intellectual (2011) offer alternatives of thinking from South African locations.

Perhaps one of the finest contributions of this book is its ability to locate South African intellectual traditions within global conversations in order to illustrate that knowledge, like people, moves and is fluid. It is difficult and perhaps less productive to pin it down to a particular place, time, person or institution. Traditions arise in dialogue, in cross currents, across temporalities and in how ideas find resonance to advance particular courses. We can thus have a rural community in the Transkei keenly influenced by black Americans whom they believed would rescue the black person from the colonising menace of the British. Ndletyana tells us that their hopeful refrain was "amaMelika ayeza". Moments under the rubrics of Ethiopianism and Garveyism are captured by the thriving black press such as Umteteli Wendaba and are illustrations of old solidarities and inspirations deriving from the diaspora. The circling of these traditions in the black world underscores the pervasiveness of racism across the world. Soga, Jabavu, Mqhayi and others together with the black press are testaments of African intellectual agency and made landmark contributions to an important strand in South African intellectual traditions.

Like the book, this review is broadly narrow. Brevity does not allow for adequate engagement with the diverse themes covered. In the limited available space, I must reiterate that any scholar that is serious about reflecting on the local context would do well to read this book. Years from now, it will continue to be the go to book to orient readers to the history of diverse areas of interest including religion, black thought and Pan Africanism, liberalism, Afrikaans intellectual thought and other themes. There are of course other works which provide a broad and deep analysis of these topics. For Afrikaans thinking, one can read Giliomee. For feminist intellectual thought, Meintjies and Gqola are useful. For religion, Pauw is an important resource. Hofmeyr has written extensively about the history of India - South Africa relations. Dubow provides a history of apartheid. But if one needs a quick reference which provides a focused and scholarly summary of all of these strands, Intellectual traditions in South Africa is highly recommended.

\section{References}

Steyn, M (2001) "Whiteness just isn't what it used to be": White identity in a

changing South Africa. New York: State University of New York Press.

Mangcu, X (2012) Biko: A biography. Cape Town: Tafelberg.

Mokoena, H (2011) Magema Fuze: The making of a Kholwa intellectual.

Pietermaritzburg: UKZN Press. 